Mineralogy and

Geochemistry of a

Uraniferous Coal from the

Red Desert Area,

Sweetwater County, Wyoming

By I. A. Breger, Maurice Deul, Robert Meyrowitz, and Samuel Rubinstein

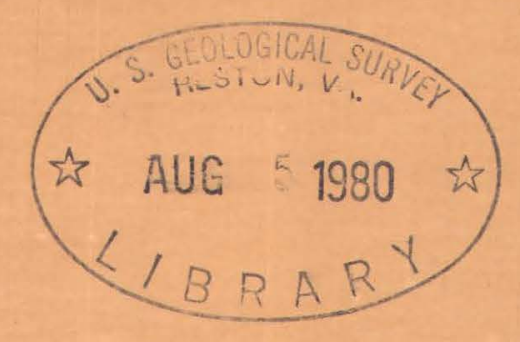

Trace Elements Investigations Report 389

UNITED STATES DEPARTMENT OF THE INTERIOR GEOLOGICAL SURVEY 
Geology and Minera.logy

This document consists of 19 pages. Series A。

UNITED STATES DEPARTMENI OF THE INIERIOR

GEOLOGICAL SURVEY

\title{
MINERALOGY AND GEOCHEMISTRY OF A URANIFEROUS COAL FROM THE \\ RED DESERT AREA, SWEETWATER COUNTY, WYOMING*
}

\author{
By \\ Irving A. Breger, Maurice Deul, Robert Meyrowitz, \\ and Samuel Rubinstein
}

Auguat 1953

Trace Elements Investigations Report 389

This preliminary report is distributed without editorial and technical review for conformity with official standards and nomenclature. It is not for public inspection or guotation.

* This report concerns work done on behalf of the Division of Raw Materials of the U.S.Atomic Energy Commission.

When separated from Part II, handle Part I as UNCLASSIFIED。 


\section{USGS - TEI-389}

\section{GEOLOGY AND MINERALOCY}

Distribution (Series A)

American Cyansmid Company, Winchester ono $0000000000 \ldots 0000$

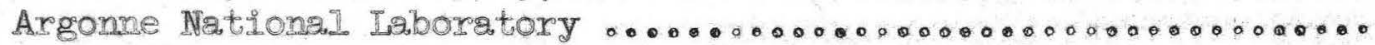
Atomic Energy Comission, Washington

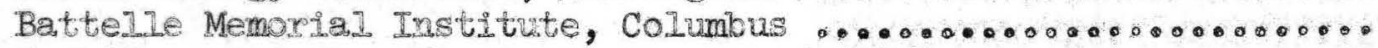
Carbide and Carbon Chemicals Company, Y-12 Area oonoono. Division of Rav Materlals, Albuguerque o o0000000000000000.0.

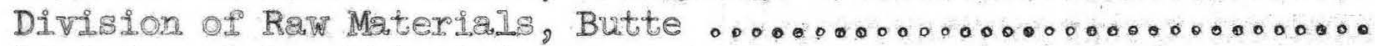

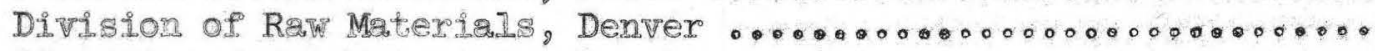
Division of Raw Materials, Douglas o00000000000000000000. DIvision of Raw Materials, Grants o. o00000000000000000000000.

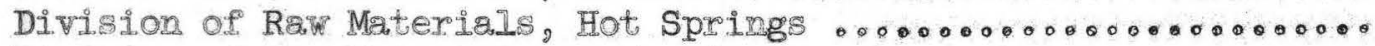

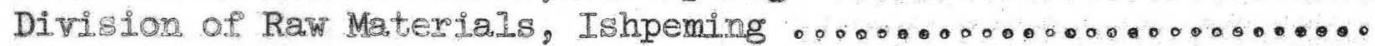

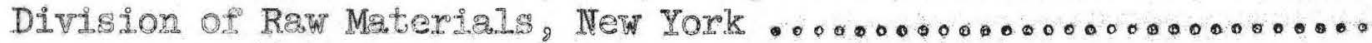
Division of Rav Materials, Phoenix o00000000000000000000000000000 Division of Raw Materials, Richfield 00000000000000000000000000 Division of Raw Materials, Salt Iake CIty o000000000000000000 Division of Raw Materials, Washington p00000000000000000000000000 Division of Researeh, Washington s000000000000000000000000000 Dow Chemical Company, PIttsburg .0000000000000000000000000000 Exploration Division, Grand. Junction Operations office o...

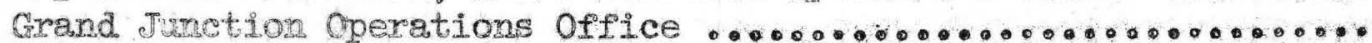
Technical Information Service, Oak Ridge no0,000000000000000 Temessee Va.17oy Authority, Wilson Dam o000000000000000000 U. S. Geologi.col Survey:

Alaskan Geology Branch, Washington , opopopocono. Fuels Braneh, Washington o0000000000000000000000000000000 Geochemistry and Petrology Braneh, Washington .00000000000. 15

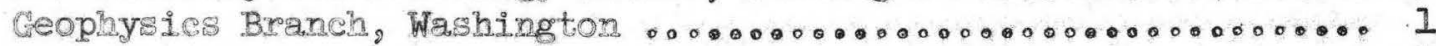
Minera. Deposits Branch, Washington 0000000000000000000000000. I E. H. Bailey, San Francisco no000000000000000000000000000000000 I K. L. Buck, Desver o00000000000000000000000000000000000000000000. I To Ro Cooper, Denver 0000000000000000000000000000000000000000000, I No Mo Denson, Denver o000000000000000000000000000000000000000000. Co. Eo Duttong Madison 0000000000000000000000000000000000000000000 R. Po Fischer, Grand. Junction 0000000000000000000000000000000.0. Is So Cardner, Albuquerque 000000000000000000000000000000000 M. R. Klepper, Washington ...000000000000000000000000000000000 A. E. Koschmann, Denver o. 00000000000000000000000000000000 R. A. Iaurence, Knoxvilie 00000000000000000000000000000000000 D. Mo Iemmon, Waskington o0000000000000000000000000000000000000 Io Do Iove, Iargmie 000000000000000000000000000000000000000000 $R_{0} G_{0}$ Petersen, Plant City 0000000000000000000000000000000000000 R. Jo Roberts, Sa, Lt Lake Clty o00000000000000000000000000000000 Q. Do Singewald, Beltsville 00000000000000000000000000000000

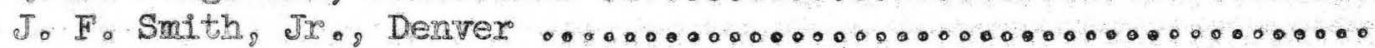

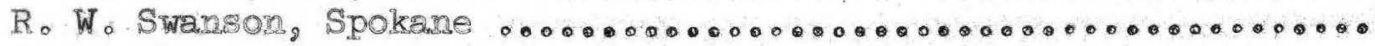
A. E. WeIssenborr, Spokane o0000000000000000000000000000000000 W. P. WIIIIams, Joplin o00000000000000000000000000000000000.0. TEPCO, Denver 000000000000000000000000000000000000000000000000000 TEPCO, RPS, Wabhington ,0000000000000000000000000000000000000000 
CONIENIS

Page

Abstrget ....

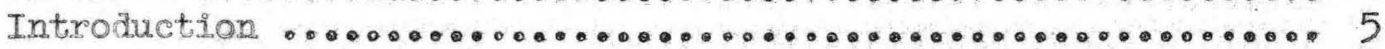

Mineralogic and geochemical studies .................... 5

Fischer assays ,

Summary and conclusions . . . o

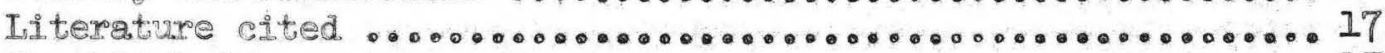

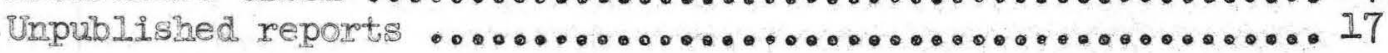

IIIUUSTRATIONS

Page

Figure 1. Schere for beary liguid separation of the minerals from the subbituminous cosl from the Red. Desert,

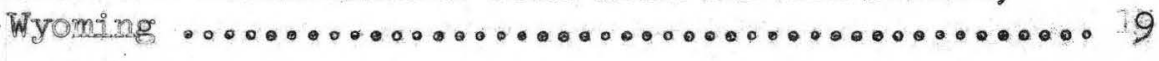

2. Ash cootent Ws. pereent uranium in the ash for severa. sieve fractions from a sample of the

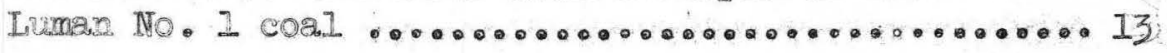

\section{TABLES}

Page

Table 1. Analyses of sieve fractions obtained from a sample of Luman No. 1 cor. used for mineralogie studies ... 7

2. Semiquantitative spectrographic analyses, in percent, of the ash from a sample of the Luman No. I cos.

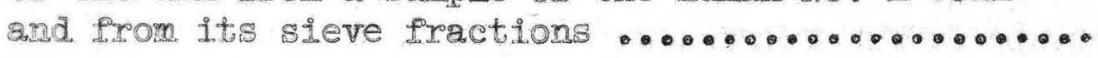

3. Estimated mineral content of a sample of Iuman No. I $\cos 1$

4. Retort assays of subbituminous coal from the Red

Desert, Wyoming, and of lignite from Milam County,

Texas 
MINERALOGY AND GEOCHEMISTRY OF A URANIFEROUS COAL FROM THE RED DESERT AREA, SWEETWATER COUNPY, WYOMING

by

Irving A。 Breger, Maurice Deul, Robert Meyrowitz, and Samuel Rubinstein

\section{ABSTRACT}

A sample of subbituminous uraniferous cosl from the Red Desert, Sweetwater County, Wyo, was studied mineralogically。 The coal contains gypsum ( 6 percent), krolinite ( 1 percent), quarti ( 0.3 percent), calcite (trace), and Iimonite (trace). This suIte of minerals and the absence of pyrite show that the coal has been subjected to weathering and oxidation. No uranium minerals have been found; mechanical fractionation has indicated that the uranium is associated. with the organic constituents of the coal. The minerals that have been isolated contain 0.0006 percent uranium, a conteat which is to be expected for nonuraniferous sedimentary rocks. The organic components of the coal contain approximately 0.002 percent uranium. On the basis of material balance calculations, the organic components carry 98 percent of the uranium in the coal.

Fischer assays of this weathered coal from the Red Desert indicate a yield of 16.7 gallons of tar per ton on low-temperature retorting. In view of the large reserve of subbituminous coal in the Red Desert, its probable ease of mining, and its tar yield, it may be desirable to carry out further evaluation of the coal as a fuel or raw material for the manufacture of tar or chemicals. If economic factors permit utilization of the coal, the vranium, although present in small percentages, could be recovered. as a byproduct. 
INTRODUCTION

Preliminary geologic investigations of the subbituminous uraniumbearing coal from the Red Desert were reported. by Masursky and Pipiringos (in Denson et al., 1951) and by Masursky, Pipiringos, and Gower (1953)。 An initial report on the coal in this area has been issued. (Masursky and Pipiringos, 1953)。

In October 1952 Deul and Breger visited the Red. Desert; at this time the geology of the area was discussed in detail by Masursky. After the field conference samples were collected from the Luman No. I bed at its outcrop near the center of sec. $28, T_{0} .24 N_{0}, R_{0} 95$ Wo, Sweetwater County, Wyo. Although vaweathered coal is more desirable for mineralogic and geochemical investigations, the slightly weathered coal from the Luman No. I bed. was the only material available at the time of collection. Ceochemical and mineralogic studfes of this conl were undertaken to compare it with the urgafferous lignite from South Dakota (Breger and Deul, 1952) with regard to mode of retention of uranium in view of the difference in rank between the two coals. To conduct this investigation it was first necessary to determine the distribution of uranium between the separable minerals and the organic components of the coal.

\section{MLNERALOGIC AND GEOCHEMICAL STUDIES}

A sample of the coal from the upper foot of the Luman No. I bed was crushed to approximately $-\frac{1}{4}$ in. in a jaw crusher after which the material was thoroughly mixed on a large tray. The homogenized coal was then quartered, and one quarter was used for the experimental mineralogic and chemical work described below. This quarter of the coal was further crushed 
by hand until it completely passed a 20-mesh screen. Analyses of severa. of the sieve fractions obtaiaed from this coal are shown in tables I and 2.

A mechanical separation of the mineral constituents from the coal was performed using essentially the same techniques which had been found satisfactory for the coal from Harding County, S. Dak. (Breger and Deul, 1952). Ifquids of specific gravity 1.55, 1.56, 1.57, and. 1.58 (carbon tetrachloride alone or in admixture with beazene) were prepared for sinkflost experiments. Microscopic examination of the separates showed that use of mixtures of benene and carbon tetrachloride having specific gravities of 1.55 and 1.56 did not lead to appreciable fractionation of the minera. Is from the coal. In these separations the coal tended to distribute itself between the float and sink fractions in proportions not representative of the actual mineral content of the coal as indicated by ash determinations. Carbon tetrachloride alone (sp gr 1.57) was eventually chosen for float-sink separations as it yielded a highossh sink fraction corresponding approximately In 6 ize to the known ash content of the coal.

Using carbon tetrachloride (sp gr 1.57), a heavy fraction was obtained. which accounted for 8 percent by weight of the original coal. This fraction had an ash content of 89.6 percent and contained. 0.0006 percent uranium in the ash. The float from this separation accounted for 92 percent of the coal, contained 9.5 percent ash, and 0.020 percent uranium in the ash. Figure I shows the scheme of these separations and data for succeeding mineralogic fractionation.

The $-100+200$ mesh coal was chosen for this work because mixed grains of this size could be easily separgted for ident ffication. It is recognized that certain minerdis may be selectively concentrated in sieve sizes other than the $-100+200$ fraction which was taken for this work. As is indicated 
Table 1.-Analyses of sieve fractions obtained from a sample of luman No. 1 coal used for mineralogic studies

$\begin{array}{lcccc}\text { Sieve fraction } & \begin{array}{c}\text { Percent of } \\ \text { sample }\end{array} & \begin{array}{c}\text { Ash, dry basis } \\ \text { (percent) }\end{array} & \begin{array}{c}\text { U in dry ash } \\ \text { (percent) }\end{array} & \begin{array}{c}\text { in dry coal } \\ \text { (percent) }\end{array} \\ -20+50 & 51.6 & 10.45 & 0.0175 & 0.0018 \\ -50+100 & 21.1 & - & - & 0 \\ -100+140 & 7.1 & 12.66 & 0.0154 & 0.0020 \\ -140+200 & 5.0 & 14.2 & 0.0130 & 0.0019 \\ -200+230 & 2.9 & 15.0 & 0.0125 & 0.0019 \\ -230+325 & 1.9 & 23.46 & 0.0077 & 0.0018 \\ -325 & 10.4 & 196 & 0\end{array}$

$\begin{array}{llll}\text { OrIginal cogl } & 13.11 & 0.0165 & 0.0023 \\ \text { (average of six } & & & \\ \text { analyses) } & & \end{array}$

in table 2, gypsum apparently concentrates in the -325 mesh fraction under the conditions of grinding that were employed. This fraction, however, accounts for only about 10 percent of the coal. It is evident from tables 1 and 2 that the $-100+200$ mesh coal which was used for these studies has an ash content, uranium content, and distribution of trace elements very similar to that of the original coal.

The fraction of the coal having a specific gravity greater than 1.57 was next put into a liquid of $\mathrm{sp}$ gr 2.0 , a mixture of carbon tetrachloride and bromoform, to effect another separation. The heavy material was now treated. With a carbon tetrachloride-bromoform mixture having a specific gravity of 2.4 to separate gypsum (sp gr 2.32) from quartz, calcite, and. Iimonite. Iimonite ( $\mathrm{sp}$ gr 3.6-4.0) was isolated from the quartz and 
Table 2.- Semiquantitative spectrographic analyses, in pereeat, of the ash from a sample of the Luman No. 1 coal and from its sieve fractions. I/

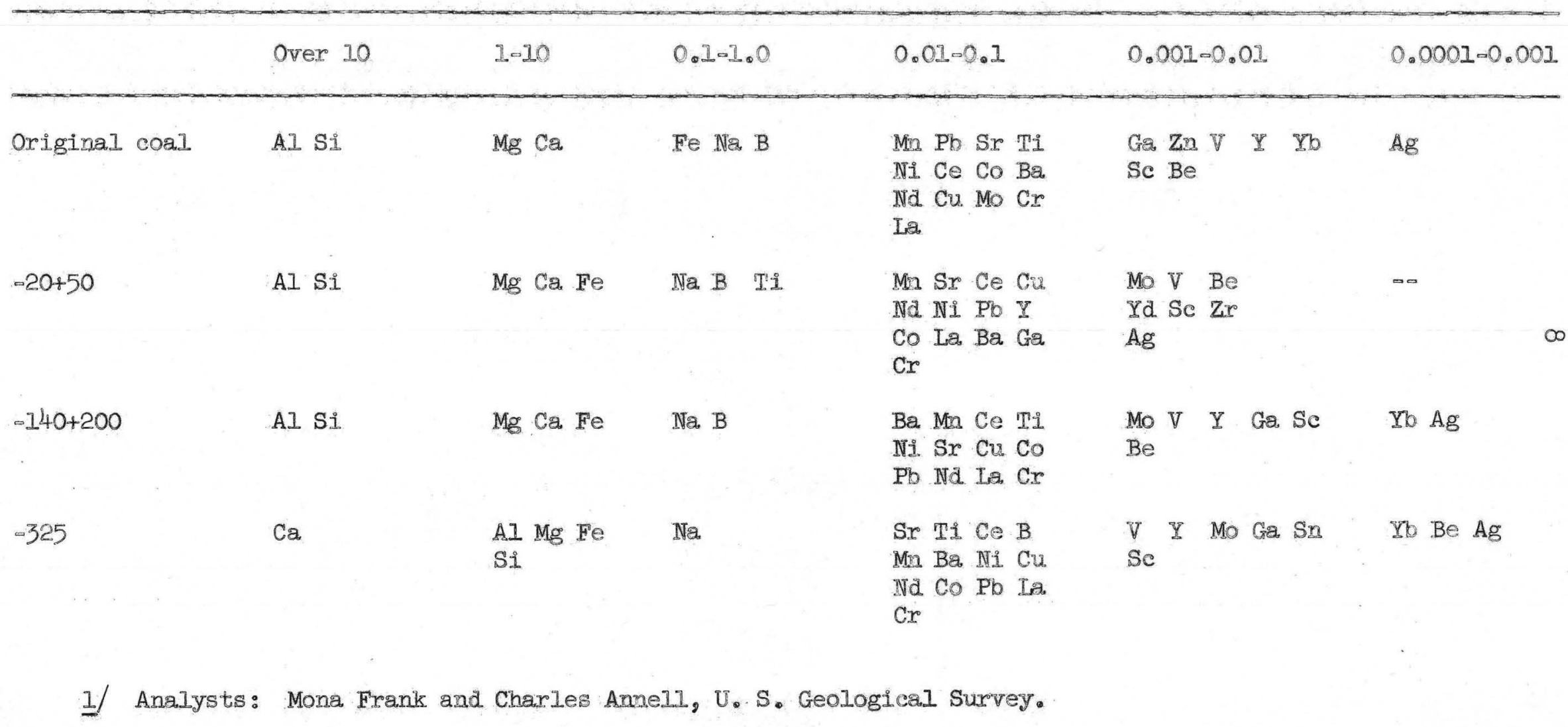


Figure 1. - Scheme for heavy-Iiquid separation of the minerals from the subbituminous coal from the Red Desert, Wyoming

OrIgingl cosI

(Avg: Ash, 13.11 percent; U in ash, 0.0163 percent)

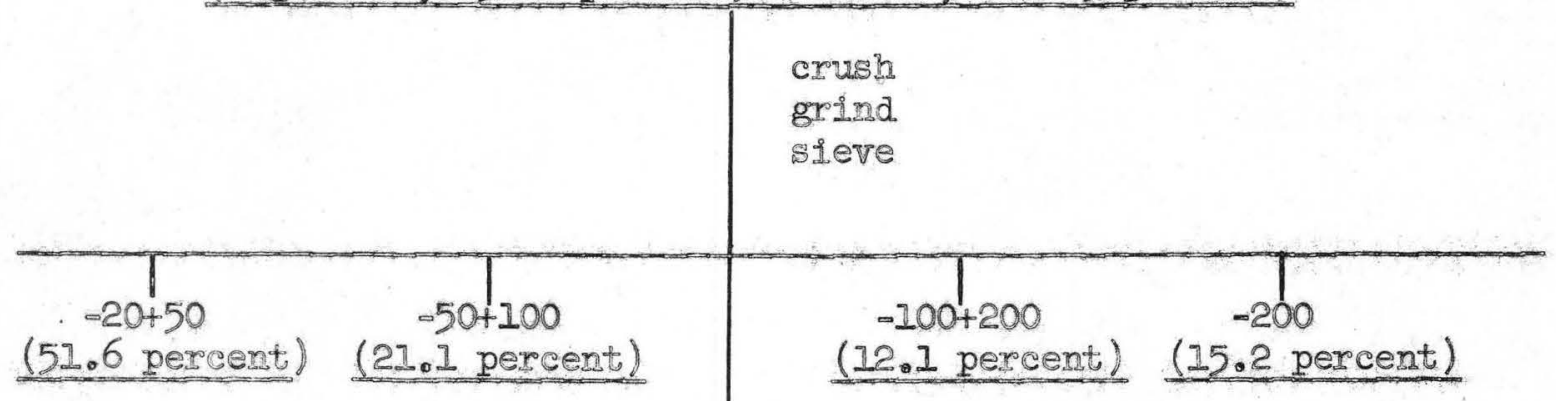

Float-sink in CCls $(\mathrm{sp}, \mathrm{gr} \cdot 1.57)$

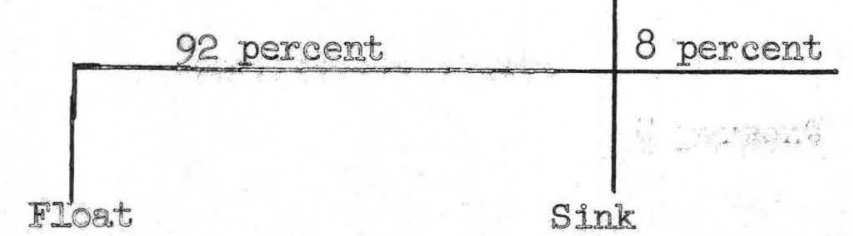

(Orgaric: Ash, 9.5

percents if in ash.

0.020 percent)

(Minerals: Ash, 89.6 percent;

$\mathrm{U}$ in $2 . \mathrm{sh}, 0.0006$ percent)

Flor.t-sink $\mathrm{CCl}_{3}+\mathrm{CHBr}_{3}(\mathrm{sp}, \mathrm{gr}, 2.0)$

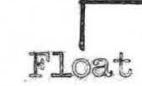

(Organie and clay minera.1s)
Sink

Minerg.1s

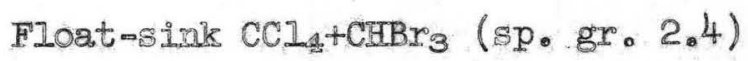

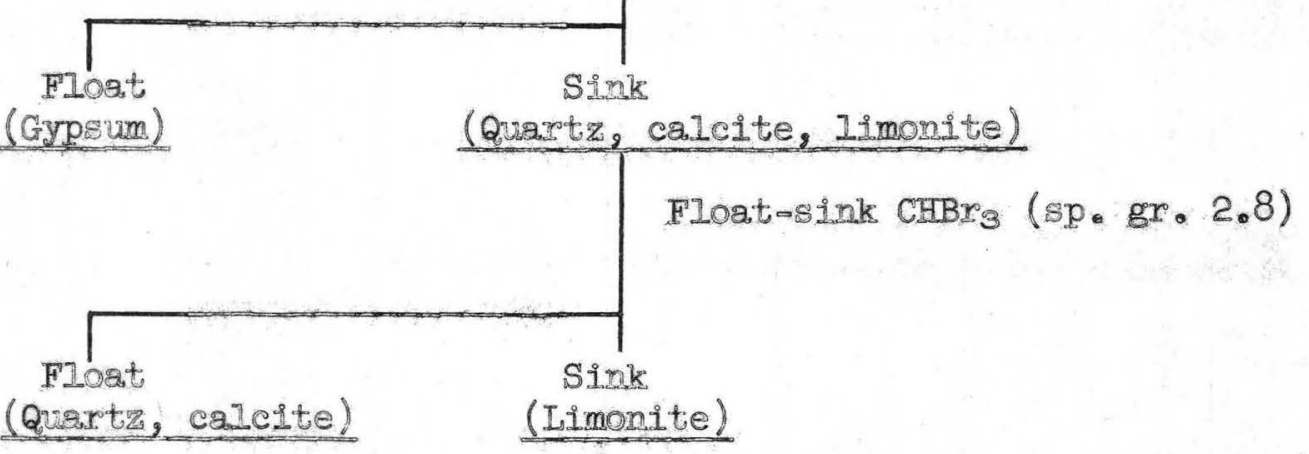


calcite by the use of bromoform (sp gr 2.8). No effort was made to separate quartz and calcite as the amount of calcite indicated by microscopic examination of the fraction was very small.

Because the minerals could not be separated completely from the organie material, it was possible only to estimate the percentages of the minerals. On the basis of these estimates, table 3 shows the approximate composition of the total mineral fraction isolated and of the percentages of the individual minerals recalculated to the original coal.

To identify the clay minerals present in the coal, the organic matter was removed from a portion of the minergl coneentrate by treatment with 30 percent hydrogen peroxide. An Xxay diffraction powder pattern of the residue from the peroxide treatment showed that kaolinite was present. It was estimated that kaolinite accounted for 10 percent of the mineral fraction.

The metrod of Himus and Basak (1949) was used in an attempt to isolate mineral matter from the coal by fine grinding in a ball mill in the presence of both kerosene and water. Although it was hoped that the minerals might concentrate in the aqueous phase and the organic components of the coal in the kerosene, analyses indicated that the ash contents of the material obtained from each phase were nearly identical. It seemed, therefore, that the procedure was not effective with this coal and no further attempts were made in this direction.

X-ray diffraction patterns of the coal from the Red Desert confirmed. the presence of quartw. An X-ray diffraction pattern of the ash from the cosl showed. Ines for quartis and anhydrite, the latter lines confirming the presence of gypsum in the original coal. Other diffraction lines were too faint to be measured.

The average uranium content of the sample of coal used in these studies is 0.0023 percent. This analysis is for coal from only the upper foot of 
Table 3.-.Estimated mineral content of a sample of Luman No. I cos.1.

Sink In $\mathrm{CCI}_{4}$ (sp gro 1.57) (pereent)

Organic matter

Cyporum

Ka.01inite

Quartiz

Calcite

Iimonite
10

75

10

3

Tre.ce

Irrace
Coal, dry basis (percent) 
the Luman No. I bed at the collection site.

The mineralogic studies that have been described point to a possible association of uranium with the organic components rather than with the minera.ls of the coal, particularly as a mineral concentrate obtained by heavy-Iiquid separation has been found to contain 89.5 percent ash and only 0.0006 percent uranium in the ash. To confirm the association of uranium. With the organic component the following studies were conducted.

A mechanical fractionation was obtained with a split of the original -20 mesh coal that had been used for the preparation of mineral separates. A sample of the coal ( $100 \mathrm{~g}$ ) was placed on a stack of sieves which was then mechanically agitated for 30 minutes. At the end of this period the sieves were separated and the fraction obtained from each sieve was weighed. Of the seven fractions that were obtained, five were analyzed for ash and uranium. The data for this experiment have been shown in table 1.

In figure 2 the percentage of uranium in the ash has been plotted against the percent ash for five of the seven sieve fractions shown in table 1. Because the uranium in the ash decreases as the ash increases, the uranium in the coal is apparently associated with the organic components rather than with the minerals.

From table 3 separable minerals from the float-sink studies are estimated to account for approximately 8 percent of the coal; the uranium content of the minerals is 0.0006 percent. Knowing the average uranium content of the total coal sample to be about 0.0023 percent (table I), solution of the following equation indicates that the uranium content of the organic components of the coal, $x$, should be about 0.0025 percent:

$$
\begin{aligned}
0.0023 & =(0.08)(0.0006)+(0.92)(x) \\
x & =0.0025 \text { pereent }
\end{aligned}
$$




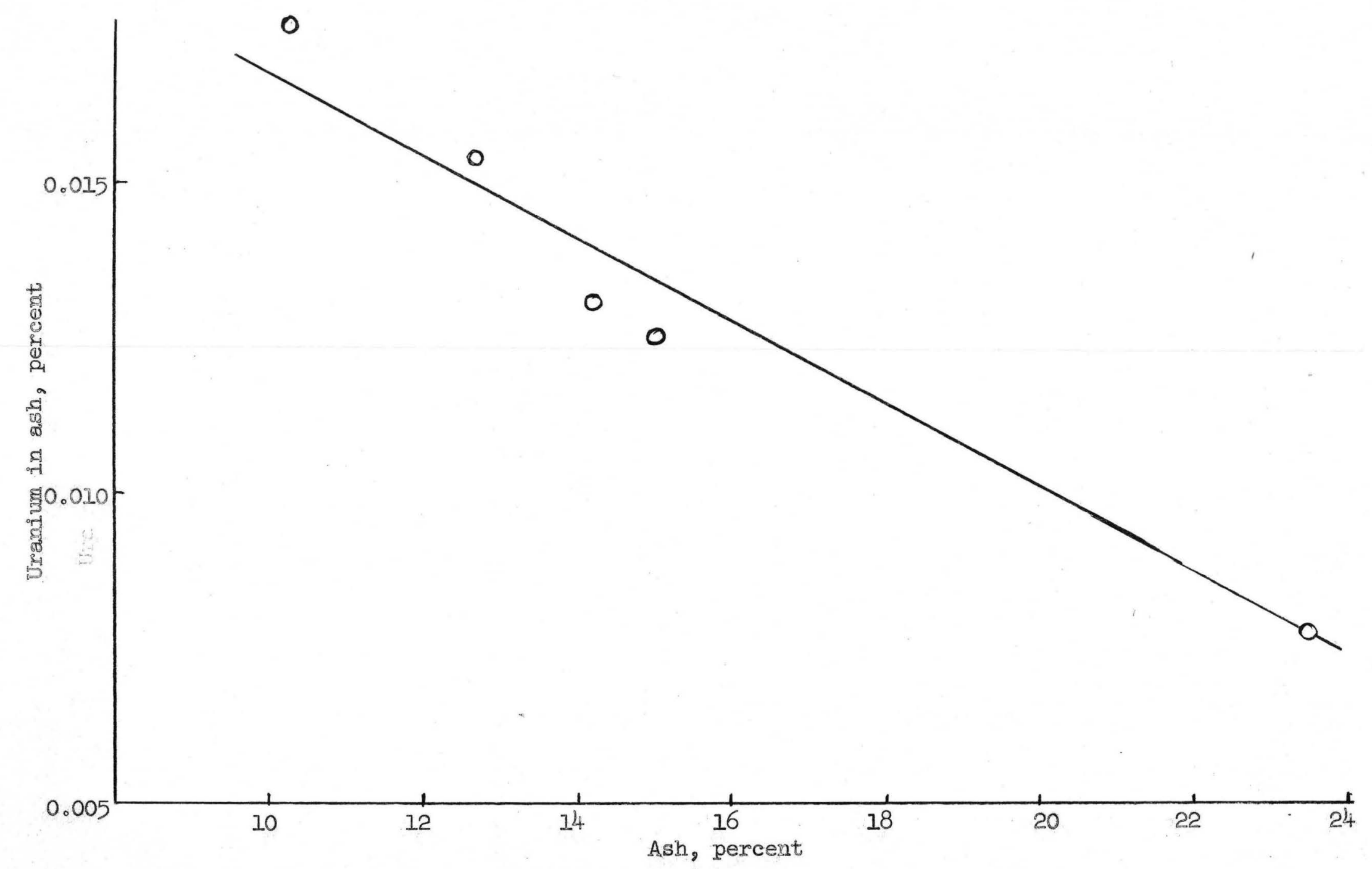

Figure 2. - Ash content vs. percent uranium in the ash for several sieve fractions from a sample of the Luman No. 1 cos. 


\section{FISCHER ASSAYS}

Fischer retort assays of a sample of the Luman No. I coal were carried out by the method described by Stanfield and Frost (1949). In this empirical procedure $100 \mathrm{mg}$ samples of coal are heated from room temperature to $500 \mathrm{C}$ in 40 minutes and maintained at that temperature for 20 minutes. The tar, water, and char produced are collected and weighed.

In table 4 average data for duplicate assays of Luman No. I coal show the yield of tar on low-temperature distillation to be 16.7 gallons per ton. This yield is compared with the 26 gallons per ton produced from the Sandow lignite of Milam County, Texas, the only low rank coal currently being treated in this country for the production of low tempersture tar. The assay data for the Sandow lignite shown in table 4 have been reported by Parry, Goodman, and Gomez (1950) who used a precision assay technique. Results of retort studies of the Sandow lignite using a large scale fluidized technique have also been publisbed recently (Parry et al., 1953) and are reproduced in table 4 for comparison. The precision assay technique of Parry, Goodman, and Gomez leads to tar yield.s sightly bigher than those obtained with the Fischer assay; the yields from the precision assay technique are comparable with those from the large-scale fluldized unit。

\section{SUMMARY AND CONCLUSIONS}

The separable minera.ls from the Luman No. 1 coal account for only about half the ash content of the coal. The remaining ash mast come from nonseparable minerals, from inherent ash which is derived from the original 
Table 4.o-Retort assays of subbituminous coal from the Red Desert, Wyoming, and of Iignite from Milam County, Texas.

All data are reported on moisture and ash-free basis.

\begin{tabular}{|c|c|c|c|}
\hline Type of assay & Fischer & Parry & Fluidized \\
\hline Coal $\quad \cdots$ & Red Desert & Sandow & Sandow \\
\hline Rank & Subbituminous & Irignite & Ifignte \\
\hline Source & Wyoming & Texas & Texas \\
\hline \multicolumn{4}{|l|}{ Yields, percent } \\
\hline Char & 57.0 & 61.9 & 71.6 \\
\hline Tar & 6.8 & 10.5 & 10.7 \\
\hline Water & 12.8 & 7.6 & 7.5 \\
\hline \multirow[t]{2}{*}{ Gas and loss } & 23.4 & 12.8 & 10.2 \\
\hline & 100.0 & 100.0 & 100.0 \\
\hline Yields, per ton & & & \\
\hline Char, Ib & 1140 & 1382 & 1432 \\
\hline Tar, gal & 16.7 & $($ Approx.) $\quad 27$ & 26 \\
\hline Water, 1b & 256 & 152 & 150 \\
\hline
\end{tabular}


plant material, and from ashoforming elements-mostly metallic.

The presence of kaolinite, quarta, and calcite is not unusual in coal (Sprunk and O'Donnell, 1942). However, the presence of gypsum and limonite and the absence of pyrite show that this sample of coal has been subjected to weathering and oxidation.

Minerals isolated mechanically from the Luman No. I coal contain only 0.0006 percent uranium and account for only 2 percent of the uranium. of the dry coal. As it bas been estimated that igneous rocks contain 0.0004 percent uranium (Rankama and Sahama, 1950) and as sediments probably contain approximately the same content of uranium (Breger, 1953), the minerals isolated from the coal from the Red Desert exhibit no appreciable exrichment of uraaium. The uranium in the coal, therefore, is associated with the organic components of coal. A similar association has a.Iready been demonstrated for the lignite from Harding County, S. Da,k. (Breger and Deul, 1952). These studies have provided data to support the suggestions of field geologists that the uranium is associated with the organic components of these coals.

Retort assays of the coal from the Red. Desert have shown that its yield of tar is not as high as that obtained from the Sandow lignite which is currently being used commercially. The yields of tar and char from the Red Desert coal, however, may be sufficiently high to give the coal commercial value for purposes other than as a fuel. It is known that weathering of coal decreases the yield of tar. Unweathered coal from the Red Desert should yield more tar. 
Himus, G. Wo, and Basak, G. C., 1949, Ana.lysis of coals and carbonaceous materials containing high percentages of inherent mineral matter: Fuel, v. 28, p. $57-65$.

Parry, V.Fo, Goodman, J. B., and Gomez, M., 1950, Low - temperature distillation assays of representative western United States coals: Co10. School of Mines Quart., V. 45, no. 2-A, p. 133-162.

Parry, V.Fo, Landers, W. S., Wagner, E. O., Goodman, J. B., and Lammers, $G_{0}$ C., 1953, Drying and carbonizing fine coal in entrained and fluidized state: U. S. Bur. Mines Rept. Inv. 4954.

Rarkama, Ko, and Sahama, Th. Go, 1950, Geochemistry, University of Chicago Press, p.632.

Sprunk, G.Co, and O'Donnel1, Ho.Jo, 1942, Mineral matter in coal: U. S. Bur. Mines Tech. Paper 648.

Stanfleld, K. E., and Frost, I. Cog 1949, Method of assaying oil shale by a modified Fischer retort: U. S. Bur Mines Rept. Invo 4477.

\section{UNPUBLISHED REPORTS}

Breger, I. A。, 1953, Unpublished data.

Breger, I. Ao, and Deul, M., 1952, Status of investigations on the geochemistry and mineralogy of uraniferous lignites: U. S. Geol. Survey Trace Elements Irav. Rept. 284.

Breger, I. A., Meyrowitz, R, and. Warr, Jo Jo, Jr., 1953, Extraction of uranium from the Red. Desert cor.l of Wyoming: U. S. Geol. Survey Trace Elements Inv. Rept. 372.

Denson, No Mo, Bachman, Go Oe, GIII, Jo R. Hail, W. Jo, Jr., Iove, J. Do, Masursky, Ho, Moore, Go Wo, Pipiringos, Go N., Vine, Jo. D., and Zeller, H. D. 1951, Summary of uraniumbearing cos., lignite, and carbonaceous shale investigations in the Rocky Mountain Region during 1951: U. S. Geol. Survey Trace Elements Memo. Rept. 341.

Masursky, Ho, and Plpiringos, G. No, 1953, Uramium-bearing coal in the Red Desert, Great Divide Basin, Sweetwater County, Wyoming: U. S. Geol. Survey Trace Elements Memo. Rept. 601.

Masursky, H., Plpiringos, G. N., and Gower, H. D., 1953, Results of exploratory core drilling for uranium-bearing coal in the northern part of the Red Desert area, Sweetwater County, Wyoming: U. S. Geol. Survey Trace Elements Inv. Rept. 332. 


\section{8 \\ USGS - TEI -389 - Part II}

\section{RECOMMENDATIONS}

Although the subbituminous cos. from the Red. Desert contains only 2. small percentage of uranium, its relatively low ask content and its yield of tar on retorting are of interest. Previous reports describing the distribution of uranium in the coal beds in the Red Desert area indicate that it may be possible to block out an area of the Red. Desert and to mine selectively only that cosl which contains the most uranium. Masursky and Pipiroingos (1953) have estimated the reserves of coal that probably can be mined by stripping.

The Luma No. 1 conl offers attractive posaibilities for commercial utilization and for recovery of uranium as a byproduct. Possible procedures for recovery of uranium from the coal have already been reported (Breger, Meyrowit, and Warr, 1953).

In view of these comsiderations it is felt that further studies of coal in the Red Desert area, should be developmental. In particular the following possibilities are suggested for further work which would best be condueted by other organizations:

1. Study of the distillstion of the coal for the production of Iowor high-temperature tar accompanied by a process for the removal of its uranium. A commercial plant for this purpose within or close to the Red Desert area would produce as major products a uranium concentrate, char for use as a fuel, and a conl concentrate in the form of tar which could be easily shipped to industrial centers. 


\section{OFFICIAL USE ONLY}

19

2. Because of its rank, the coal from the Red Desert may be of interest in the hydrogenative synthesis of chemicals and fuel.

In view of the low percentages of uranium in the coal from the Red Desert, it would seem that recovery of uranium will be dependent upon utilization of the coal. If economic factors are such that utilization of the coal becomes a reality, then it should be possible to recover the uranium as a byproduct. 